\title{
The Development of Multicultural Education Implementation Model in Social Science Learning using Contextual Teaching and Learning (CTL)
}

\author{
Akhmad Arif Musadad ${ }^{1, *}$, C. Dyah Sulistyaningrum I ${ }^{2}$, Leo Agung $\mathrm{S}^{3}$ \\ ${ }^{1}$ Historical Education Study Program, Sebelas Maret University, Indonesia \\ ${ }^{2}$ Office Administration Education Study Program, Sebelas Maret University, Indonesia \\ ${ }^{3}$ Historical Education Study Program, Sebelas Maret University, Indonesia
}

Received 18 September 2018

Revised 06 December 2018; Accepted ... December 2018

\begin{abstract}
This research aimed to describe the development of multicultural education implementation model in Social Science learning using Contextual Teaching Learning (CTL) in Junior High Schools of Surakarta City, including: (1) description of model validation result by expert team, (2) description of model field trial result, and (3) description of final model form.

This research was conducted using research and development design. The subject of research consisted of students and Social Science teachers in Junior High Schools of Surakarta City. This research was conducted in three stages: (1) preliminary study, (2) model development, and (3) model evaluation. Preliminary study was conducted in the first year, and the result was used as the basis for conducting the next stage in the second year. In the second year, model was developed in the following procedure: (1) development and readability test, (2) model validation test by expert team, (3) model trial in the field, and (4) model perfection. The results of research were as follows. (1) Expert team's evaluation on multicultural education implementation draft model and set in Social Science learning using CTL involve six aspects: a) learning model structure, b) learning model advantage, c) learning model effectiveness, d) learning model visibility, e) learning set, and f) learning guidance. The expert team's mean score on learning draft model and set is 3.48 . It means that expert team considered that multicultural education implementation model in Social Science using CTL is good. (2) Individual trial obtained mean score of 3.45. The mean score of group trial increased to 3.53 and the score of small-scale trial increased to 3.58. So, overall the participants of trial considered that the model developed was very good. (3) The final form of multicultural education implementation model in Social Science learning using CTL included: rationale, definition, syntax of model, and objective and learning implementation plan.
\end{abstract}

Keywords: Multicultural Education, Social Science, Contextual Teaching Learning (CTL.

\section{Introduction}

The objective of Social Science education is to build students to be good citizens having

\footnotetext{
* Corresponding author. Tel.:

Email: akhmadarifmusadad@staff.uns.ac.id

https://doi.org/10.25073/2588-1159/vnuer.4174
}

knowledge, skill, and social care useful to themselves, society, and state. To achieve the objective, the learning objective should involve cognitive, psychomotor, and affective aspects (Sumaatmadja, 2007). Thus, Sardiman (2010) confirms that Social Science lesson still criticize widely due to material density, 
cognitive characteristics, and recitation. Social Science learning is less interesting, boring, and dry due to containing inadequate important and beneficial values to equip students to live within society.

In this very rapid science and technology advance era, high-quality resource (HR) development is a must. HR development should be in line with values development implied in Social Science education. Those values are: educative, practical, theoretical, philosophical, and divine values. It means that Social Science subject is responsible for building young generation's character as democratic and responsible citizens.

The objective of social science teaching, particularly in social studies definition, involves three educational aspects: humanistic education, social civic education, and intellectual education. Meanwhile, Sumaatmadja (1998) explains that Social Science aims to develop students' potency in order to be sensitive to the improvement of any discrepancies occurring and dealing skillfully with any daily problems, befalling both themselves and the public. Furthermore, for students to live within society with interrelation and interdependency principles later, Zhao (2010) recommends the schools to equip students with skill, knowledge, and values.

This role and function of school can be implemented maximally, when every Social Science teacher realize the importance of social empowerment. Several phenomena often occur recently: poor sense of crises among governmental officials, fading nationalism, highly potential disintegration, anarchistic democratic spirit, mass quarrel often occurring, hoodlumism such as motor gang, and high criminality rate indicating that Social Science education implemented so far leads more to cognitive aspect, and touches less the soft skill values, and does not empower the community to be superior-cultured community. Those phenomena suggest the failure of Social Science learning in inculcating the consciousnesses of humanity, social consciousness, nationality and unity in diversity among Indonesians.

The problems above strengthen an idea of the need for multicultural education. Therefore, multicultural education should be implemented in Social Science learning. Multiculturalism education is the transfer of knowledge on life values and ideology including respect, appreciation, and tolerance to diversity developing amid plural society (Ali, 2013). Multicultural education is expected to lead the ethnic groups with different social and cultural background to attempt to develop understanding and respect to cultural diversity, to mitigate ethnocentrism, to minimize nasty prejudice against other ethnics and to improve understanding on social, economic, ethnic, and psychological differences, and to reduce the potential conflict between ethnics (Suzuki, 1999)

Multicultural education paradigm, according to Semiawan (2012), goes along with individual students' right and uniqueness learning together with others in the circumstance full of respect, tolerance, and understanding according to developmental stage and related need. Azra also supports an idea of multicultural education (Azra, 2003). The emergence of multicultural education idea is triggered with the intercultural education's success in dealing with conflict between groups and community. Intercultural education results in an attitude of ignoring minority's cultural values and even preserves social and cultural prejudices. Instead, multicultural education is expected to develop an attitude of caring about and willing to understand or the recognition of minority's culture.

Multicultural education is a reform movement and a process of creating the equality for all students in education environment. As a reform movement, the term multicultural education is still strange in the public's ears and even as a relatively new paradigm and the definition of multicultural education is still controversial among educational practitioners. As suggested by 
Anderson and Cusher (1994), multicultural education is the one concerning cultural diversity (in Mahfud, 2012). Meanwhile, Muhaemin el Mahady argues that multicultural education is the one about cultural diversity in responding to demographic and cultural change in certain community environment or even throughout world (in Mahfud, 2012).

Education problems always attributed with learning and teachers, because the role of teachers is very strategic in all educational and learning system. The 2013 curriculum requires teacher competency and professionalism, because the curriculum can be implemented well when the teachers are professional and competent (Suderadjat, 2004). The successful school reform in the context of curriculum development is highly dependent on teachers' demonstration (Mulyasa, 2013).

Teachers should not only delivery recitation material but also inculcate values developing within society. To assume strategic role and responsibility and to achieve the objective effectively, the implementation of multicultural education in Social Science learning should be managed well. Teachers should be able to integrate multicultural value in Social Science learning. Therefore it is better for teacher to use contextual teaching and learning (CTL) approach.

CTL is a learning system based on a philosophy that students can absorb lesson when they capture the meaning of material they receive and capture the meaning in school chores, when they can connect new information to experience/knowledge they have had (Johnson, 2008). CTL, according to Senjaya (2010) is the learning approach emphasizing on students' participation in the process of finding material studied and connecting it to real life situation, thereby encouraging teachers to apply it in life.

It is in line with Nurhadi in Sugiyanto (2014) stating that contextual learning (CTL) is a learning concept encouraging the teachers to connect the material taught to the real world situation of students. It can encourage students to establish the relationship between the knowledge they have and its application in their life. Students' knowledge and skill are acquired from their attempt of constructing new knowledge and skill when they learn.

The problems of research are: (1) what is the result of model validation by expert team? (2) what is the result of model field trial?, and what is the final form of multicultural education implementation model in Social Science learning using Contextual Teaching and Learning in Junior High Schools in Surakarta City?

\section{Method}

This research was conducted using research and development approach. Procedural model used in this study was adapted from Borg and Gall's (1989), and Sugiyono's (2009) model, both of which explain ten steps of research and development. The ten steps are simplified into three steps: (1) preliminary study, (2) development, and (3) product effectiveness testing stages. Preliminary study has been conducted in the first year with two action steps: exploratory study and need analysis.

This second-year research was intended to answer the problem of how the development process and the effectiveness of multicultural education implementation in Social Science learning using Contextual Teaching and Learning to improve students' creativity and social attitude in Junior High Schools in Surakarta City. To describe the problem, the following steps were taken: (1) development and readability test, (2) model validation test by expert team, (3) field trial, (4) model perfection, and (5) model effectiveness test.

Two types of data were used in this study: qualitative and quantitative. Qualitative data was obtained from the result of observation, recommendation, expert team and participants' comment on draft learning model and set. Quantitative data was obtained from questionnaires of model evaluation by expert 
team and of teacher assessment after model trial. Instrument of collecting data consisted of observation format, Likert scale questionnaire, open-ended questionnaire, and format of focus group discussion note.

The validity of instrument employed in this study consisted of construct and content validities. Data resulting from evaluation using likert scale questionnaire was analyzed using average analysis technique. Data of learning model and set evaluation by expert team and teacher analysis was analyzed using guideline of four-point scale absolute conversion. Meanwhile, data of open-ended questionnaire, observation, interview, and focus group discussion recording result analyzed using descriptive qualitative analysis technique (Miles and Huberman, 1998).

\section{Result and discussion}

\subsection{Result of research and development}

Expert team's evaluation on draft model and set of multicultural education implementation in Social Science using CTL includes six aspects: a) learning model structure, b) learning model benefit, c) learning model effectiveness, d) learning model visibility, e) learning set, and f) learning guide. The result of expert team's assessment on draft learning model and set showed that the total mean score is 3.48 . It means that expert team considers that multicultural implementation model in Social Science learning using CTL is good. The mean scoring of expert team on individual aspects and indicators of model can be seen in table below.

Table 1. Mean Score of Expert Team's Assessment on Draft Multicultural Education Implementation Model in Social Science using CTL

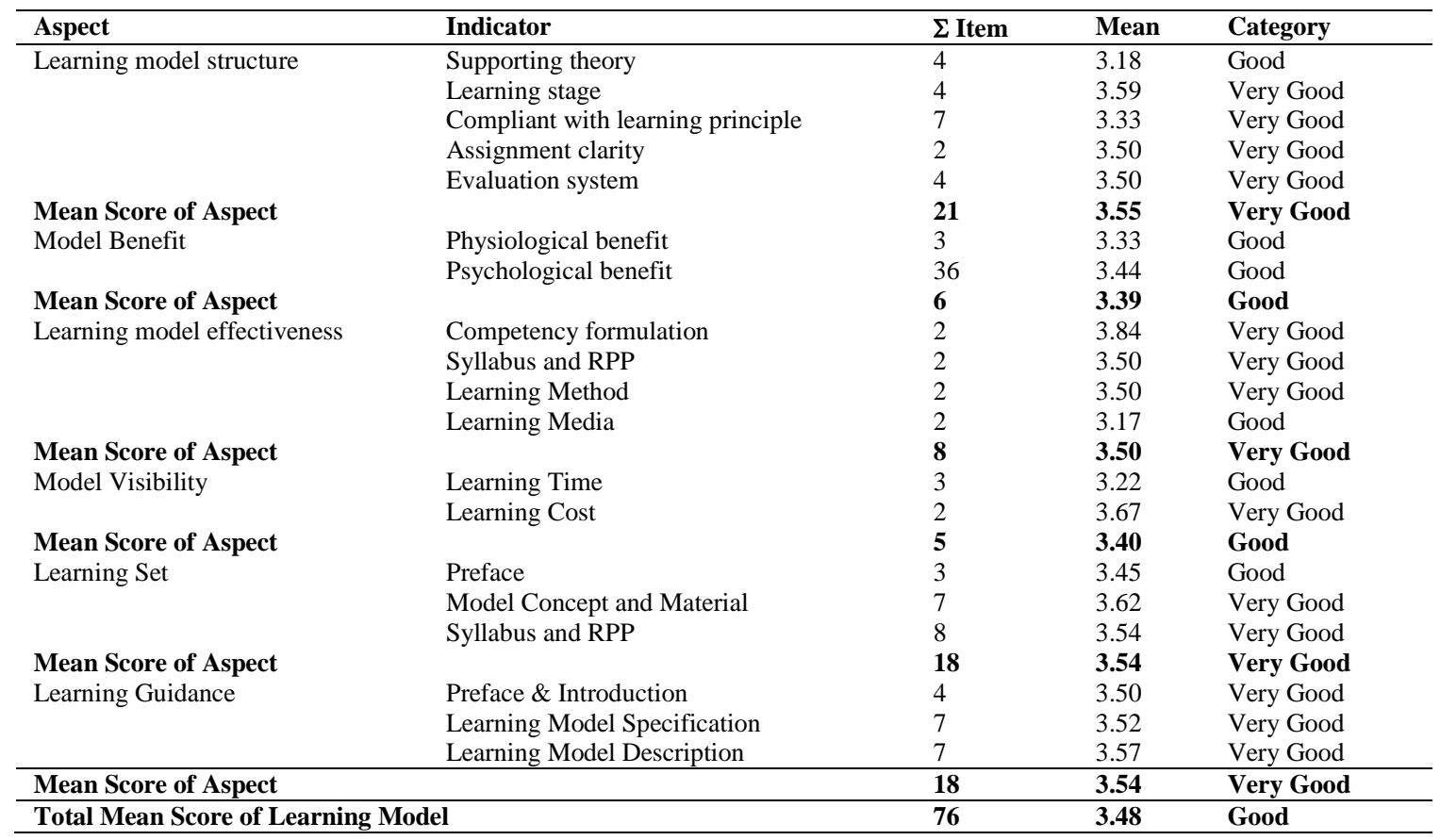

The expert team assesses that draft learning model and set is good, because this draft model is developed based on the analysis of teacher need. Teachers really need learning model that can integrate multicultural values into Social Science learning. Original draft model developed in the first-year research was then revised based on the expert team's evaluation 
result. The model revised conceptually by expert team was then trialed in the field, to obtain teacher's assessment and input.

Model trial was conducted in three repetitions: individual trial with 4 teachers, group trial with 8 teachers, and small-scale (limited) trial with 20 teachers being the subjects. The total mean score of three trials are 3.52. It means that overall the participants of trial consider that multicultural education implementation in Social Science learning using CTL is very good. Summary of participants' assessment on the model in the three trials can be seen in table below.

Table 2. Mean score of trial participants' assessment on model

\begin{tabular}{|c|c|c|c|c|c|c|}
\hline \multirow[t]{2}{*}{ Aspect } & \multirow[t]{2}{*}{ Indicator } & \multirow{2}{*}{$\begin{array}{l}\text { No. } \\
\text { of } \\
\text { Item }\end{array}$} & \multicolumn{4}{|c|}{ Mean Score of Trial } \\
\hline & & & $\begin{array}{l}\text { Individual } \\
\mathrm{N}=4\end{array}$ & $\begin{array}{l}\text { Group } \\
\mathrm{N}=8\end{array}$ & $\begin{array}{l}\text { Small-scale } \\
\mathrm{N}=20\end{array}$ & Total \\
\hline \multirow[t]{2}{*}{ Learning Form } & Learning Procedure & 4 & 3.31 & 3.50 & 3.40 & 3.40 \\
\hline & $\begin{array}{l}\text { Learning } \\
\text { Implementation }\end{array}$ & 5 & 3.55 & 3.58 & 3.62 & 3.58 \\
\hline Mean Score of Aspect & & & 3.44 & 3.54 & 3.52 & 3.50 \\
\hline \multirow[t]{4}{*}{ Learning program } & Learning objective & 3 & 3.67 & 3.75 & 3.68 & 3.70 \\
\hline & Learning method & 2 & 3.38 & 3.38 & 3.55 & 3.44 \\
\hline & Learning evaluation & 4 & 3.44 & 3.50 & 3.45 & 3.46 \\
\hline & Program target & 3 & 3.58 & 3.59 & 3.63 & 3.60 \\
\hline \multicolumn{2}{|c|}{ Mean Score of Aspect } & & 3.52 & 3.57 & 3.57 & 3.55 \\
\hline \multirow[t]{3}{*}{$\begin{array}{l}\text { Learning Teaching } \\
\text { Material }\end{array}$} & $\begin{array}{l}\text { Quality of Teaching } \\
\text { material }\end{array}$ & 4 & 3.31 & 3.44 & 3.55 & 3.43 \\
\hline & $\begin{array}{l}\text { Instructional } \\
\text { Analysis }\end{array}$ & 3 & 3.25 & 3.59 & 3.67 & 3.50 \\
\hline & $\begin{array}{l}\text { Teaching Material } \\
\text { Relevance }\end{array}$ & 2 & 3.63 & 3.38 & 3.78 & 3.60 \\
\hline Mean Score of Aspect & & & 3.36 & 3.47 & 3.64 & 3.49 \\
\hline Total Mean Score & & 30 & 3.45 & $\mathbf{3 . 5 3}$ & 3.58 & 3.52 \\
\hline
\end{tabular}

Considering the result of participants' assessment on model trial in the field, the model was then perfected into the final form of multicultural education implementation model in Social Science learning using CTL. The final form of model intended is illustrated in the figure below.

Figure of Final Multicultural Education Implementation Model in Social Science using CTL

\section{Description of Model}

The objective of Social Science learning corresponding to the 2013 curriculum is to inculcate knowledge, skill, attitude, and value so that students can be good citizens and members of society. The 2013 curriculum requires the improvement of teacher competency and professionalism in managing teaching-learning process, in order to improve students' knowledge, skill, and attitude. Therefore, teachers are expected to implement multicultural education in Social Science learning, to enable the students living in plural society to have creativity and social solidarity. The students are expected to think creatively in treating Ethnicity, Religion, Race and inter-group relations (thereafter called SARA) issues developing, and to have social attitude in dealing with community with diverse background. A model recommended by the 2013 curriculum for Social Science learning is Contextual teaching and learning.

Social Science learning using CTL is a conceptual framework becoming the teachers' guideline in implementing Social Science learning, integrated into multicultural values in programmed and planned manner. 
This model application aims to equip students with knowledge, skill, and attitude in order to have creativity and social attitude that can be manifested into plural society life. This model has some stages: constructivism, inquiry, questioning, Learning Community, modeling, reflection, and authentic assessment.

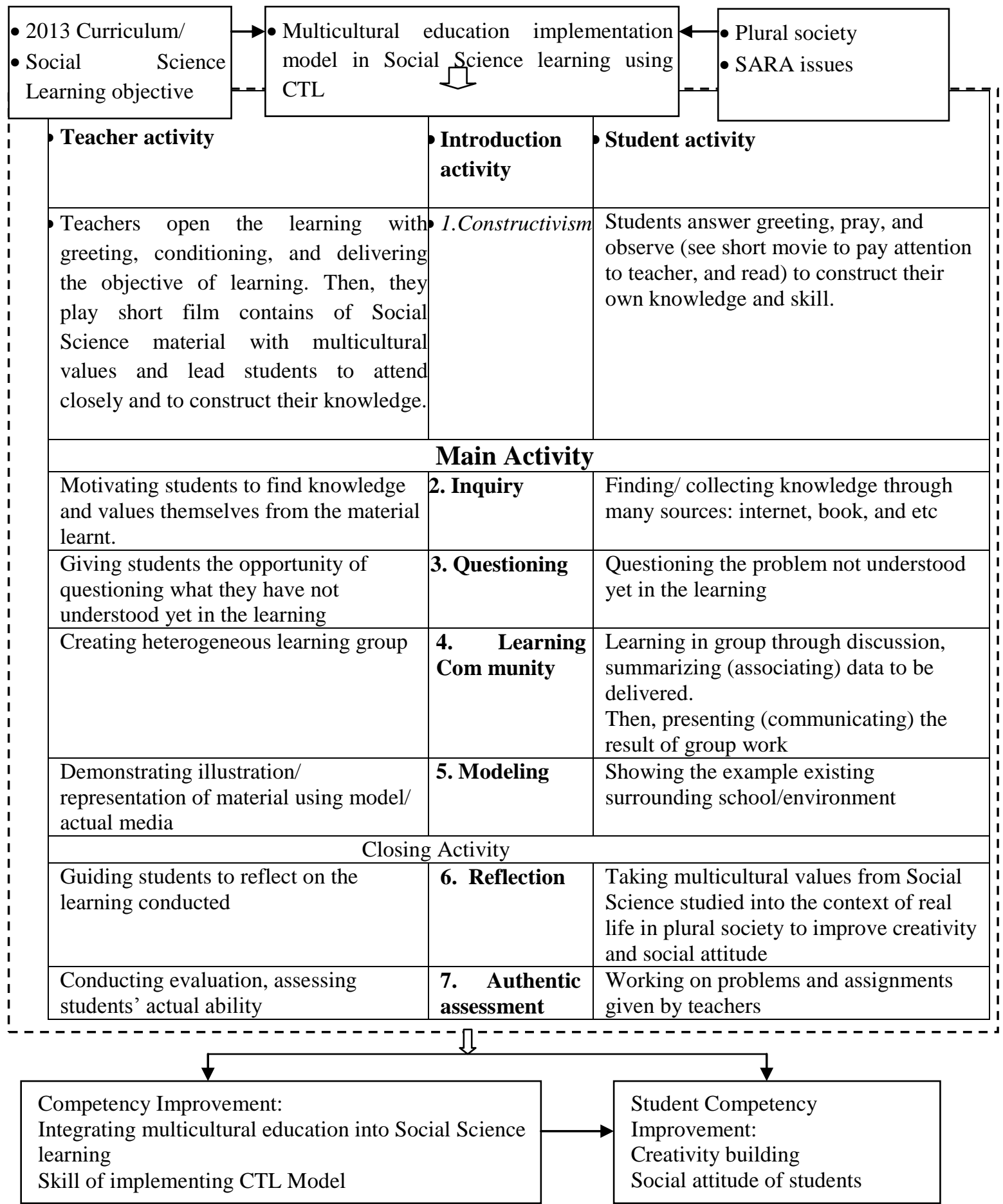


Every stage in this model should indicate the teachers' attempt of inculcating multicultural values.. The main goal of multicultural education in Social Science learning using CTL is not only the transfer of value to students, but also the improvement of their creativity and social attitude.

\section{Discussion}

The mean score of expert team's assessment on draft Social Science learning model and set using CTL is 3.48. It means that the multicultural education implementation model in Social Science learning using CTL is considered as good by expert team. Despite expert team's good scoring on draft model, they give some inputs or recommendations related to the conceptual aspect of model. The expert team's recommendation becomes the material to revise the model. The model revised based on expert team's input and assessment is then trialed in three repetitions. Individual trial with 4 teachers being the subjects obtains mean score of 3.45 , meaning that teachers consider the multicultural education implementation model in Social Science learning using CTL good. Then, group trial with 8 teachers being the subjects obtains mean score of 3.53, meaning that teachers consider the model very good. Finally, in small-scale trial with 20 teachers being the subjects, the mean score increases to 3.58. The total mean score of the three trials is 3.52 . It means that overall the participants of trial consider that the multicultural education implementation in Social Science learning using CTL is very good. Furthermore, the participants of field trial' input (recommendation) and assessment are used to perfect the model. The final multicultural education implementation model using Social Science learning using CTL includes: model rationale, definition, syntax, and objective.

The model developed is considered as good conceptually by expert team and its applicability in the field is also considered very good by teachers in model trial, because multicultural education implementation model in Social Science learning using CTL is designed and developed considering the result of preliminary study and teacher need analysis. So far, teachers emphasize more on cognitive aspect in their learning, containing recitation material less appropriate to the real condition students deal with in living within society. So far, Social Science learning, according to Sardiman (2010), is too replete with cognitive and recitation material. Because it emphasizes on teaching material, Social Science learning is entrapped into the process of collecting information and fact. Because it is oriented to cognitive aspect and recitation, Social Science learning is boring, uninteresting, and considered by students' burden.

Social Science learning not only contains knowledge with various facts and material students should recite, but also should build students' mentality that is aware of their responsibility to their own right and obligation to society, nation, and state (Wahab, et al., 2012). It means that Social Science learning not only presents social knowledge, but also serves as a means of building students to be members of community and citizens who are responsible to community, nation and state (Sumaatmadja, 2007). Social studies are not only limited to the cognitive material, but also include values compulsorily inherent to students. The inculcation of values is really beneficial when it is administered to young children in Elementary and Junior High Schools. Multiculturalism is something real always faced and encountered by students in living within both school and society. Therefore, the development of multicultural education implementation model in Social Science learning using CTL is very desirable. Ali (2012) confirms that multiculturalism education is the transfer of knowledge about life values and ideology of respect, appreciation, and tolerance to diversity developing amid the plural society. 


\section{Conclusion and recommendation}

\subsection{Conclusion}

Expert team considers the draft multicultural education implementation model in Social Science learning using CTL good. Expert team gives recommendation and assessment on the model of aspect: model structure, benefit, effectiveness, visibility, learning set, and manual instruction.

After the draft model has been revised according to the expert team's recommendation, it is then trialed in the field. The result of participants' assessment on draft model improves gradually. The mean score of individual trial on draft model is 3.45 , meaning that the draft model is good. Then, the mean score of group trial increases to 3.53 (very good) and the mean score of small-scale trial increases to 3.58 (very good).

The result of trial participants' assessment and recommendation is taken into account to perfect the model, thereby yielding the final form of multicultural education implementation model in Social Science learning using CTL. The final form of model consists of: model rationale, definition, and syntax involving teachers and students' activities in learning (modified from CTL syntax), objective, and learning implementation (RPP).

\subsection{Recommendation}

1. Teachers are recommended to apply multicultural education implementation model in Social Science using CTL. Because through this model, teachers can teach contextual material and integrate the material into multicultural values all at once. Multiculturalism issue is a real contextual problem students face in living within society.

2. Although the result of expert team and trial participants' assessment on this model is good, this model's limitation is that it is still trialed individually, in group, and in small-scale trial in Junior High Schools of Surakarta. To perfect this model further, those related such as
Regency/City and Province Education Services are expected to conduct trial in wider scale, for example in many regencies/cities or in other provinces.

3. The final form of multicultural education implementation model and set in Social Science using contextual teaching and learning is designed to improve students' creativity and social attitude. For that reason, future researchers and others related are recommended to develop similar learning model to improve other competencies.

\section{References}

[1] Ali, N. (2013). Multikulturalisme dalam Islam. Yogyakarta: Idea Press.

[2] Azra, A. (2003). Jakarta. http://www.kompas.com/kompas-cetak/0207/3 1/Daerah /nime28.htm. Jakarta. (retrieved on November 3, 2014).

[3] Borg, R. Walter dan Gall, Meredith D. (1989). Educational Research: An Introduction. Fifth Edition. Longman.

[4] Johnson, Elaine B. (2008). Contextual Teaching and Learning (Translation by: Ibnu Setiawan). Bandung: MLC.

[5] Mahfud, Choirul. (2012). Pendidikan Multikultura, Yogyakarta : Pustaka Pelajar.

[6] Milles, M. B. dan Huberman, A. M. (1998). Qualitative Data Analysis: A Sourcebook of a New Method. Beverly Hill: Sage Publications.

[7] Mulyasa, E. (2013). Manajemen Kekepalasekolahan: Petunjuk Praktis Menjadi Kepala Sekolah yang Profesional. Bandung: PT. Remaja Rosdakarya.

[8] Sardiman A.M. (2010). "Revitalisasi Peran Pembelajaran IPS dalam Pembentukan Karakter Bangsa". Dalam Cakrawala Pendidikan, Mei 2010, Th. XXIX, Edisi Khusus Dies Natalis UNY.

[9] Semiawan, C. (2012). Belajar dan Pembelajaran Dalam Taraf Usia Dini. Jakarta: PT.Prenhallindo.

[10] Senjaya, W. (2010). Strategi Pembelajaran; Berorientasi Standar Proses Pendidikan. Jakarta: Kencana Prenada Media Group.

[11] Suderadjat, H. (2004). Implementasi Kurikulum Berbasis Kompetensi (KBK) Pembaharuan Pendidikan dalam Undang-undang Sisdiknas 2003. Bandung: CV Cipta Cekas Grafik. 
[12] Sugiyanto. (2014). Model-Model Pembelajaran Inovatif.Surakarta : UNS Press.

[13] Sugiyono. (2009). Metode Penelitian Pendidikan: Pendekatan Kuantitatif, Kualitatif, dan $R$ \& D. Bandung: Penerbit Alfabeta.

[14] Sumaatmadja, Nursid. (1998). Metodologi Pengajaran Ilmu Pengetahuan Sosial (IPS). Bandung: Penerbit Alumni.

[15] Sumaatmadja, Nursid. (2007). Konsep Dasar IPS. Jakarta: Pusat Penerbitan Universitas Terbuka.

[16] Suzuki, B. H. 1999. "Multicultural Education: What's it All About?" Integrated Education
Journal. $\quad 17 \quad(1-2): \quad 47 \quad-\quad 48$. http://www.eric.ed.gov/ERICWeb

Portal/search/detailmini. (retrieved on December 27, 2010)

[17] Wahab, A.Z.,dkk. (2012). Konsep Dasar IPS. Jakarta: Universitas Terbuka.

[18] Zhao, Y. (2010). "Preparing Globally Competent Teachers: A New Imperative for Teacher Education". Journal of Teacher Education. 61 (5): 422-431. http://jte.sagepub.com/content/61/5/422. (retrieved on April 28, 2012). 